\title{
Safe Water, Improved Sanitation and Hygiene in Rural North-Central Nigeria: Analysis of Households' Willingness to Pay
}

\author{
(Research Article)
}

Doi: 10.29023 /alanyaakademik.430900

\section{Adeyemi Esther OMONIWA}

Department of Agricultural Economics and Farm Management, University of Ilorin, Ilorin, Nigeria (omotade29@gmail.com)

Orcid ID: https://orcid.org/0000-0003-4075-1303

\section{Raphael Olanrewaju BABATUNDE}

Department of Agricultural Economics and Farm Management, University of Ilorin, Ilorin, Nigeria(ralphag20@yahoo.com)

Orcid ID: https://orcid.org/0000-0002-3438-1054

\section{Mubashir Babatunde UTHMAN}

College of Health Sciences, University of Ilorin, Ilorin, Nigeria (uthmanmb@yahoo.com)

Orcid ID: https://orcid.org/0000-0002-3012-195X

How to cite this article: Omoniwa, A.E., Babatunde, R.O., \& Uthman, M.B. (2018). Safe Water, Improved Sanitation And Hygiene In Rural North-Central Nigeria: Analysis Of Households' Willingness To Pay. Alanya Academic Review, 2(3), 275-285.

\begin{tabular}{|c|c|}
\hline & ABSTRACT \\
\hline Keywords & $\begin{array}{l}\text { Using the Contingent valuation method, logit and tobit models this article } \\
\text { examined the willingness of rural households to pay for safe water and }\end{array}$ \\
\hline ater & improved solid waste management in North-central Nigeria. Data used was \\
\hline Household waste & collected from 352 households in North-central, Nigeria using questionnaire \\
\hline Willing-to-pay & forms. Results revealed that 27.6 percent of households were willing-to-pay \\
\hline Rural & $\begin{array}{l}\text { an average of N176/week for improved solid waste management while } 30 \\
\text { percent were willing-to-pay an average of } N 21.60 / 20 \text { liters of potable water. }\end{array}$ \\
\hline Received: 05.06 .2018 & Also, gender, years of schooling, membership of cooperative societies, \\
\hline Revision: 23.08 .2018 & dependency ratio, health status and the monthly income are the factors that \\
\hline Accepted: 24.09 .2018 & $\begin{array}{l}\text { significantly influence their willingness-to-pay. It recommended that rural } \\
\text { dwellers should be enlightened on the importance of proper waste } \\
\text { management which will result in improved environmental health. }\end{array}$ \\
\hline
\end{tabular}

\section{INTRODUCTION}

In Nigeria, life expectancy is relatively low as it is reported to be less than 55 years of age (Central Intelligence Agency World Fact book, 2015; World Health Statistics, 2014). This is because majority of the populace particularly those who live in the rural areas do not have adequate access to basic infrastructures such as safe water and improved sanitation as well as proper solid waste management. All these result in exposure to hazardous substances, unsafe public spaces, changes in lifestyles, poor water and air quality as well as poor housing conditions. The standard of living in any country can be correlated with the standard of solid 
waste management and access to improved quality drinking water. This will help to reduce the morbidity and mortality rates.

According to UNESCO (2006), it was estimated that about 1.2 billion people lack access to improve water supplies and the 2.6 billion people half of the developing world and 2 billion of who live in rural areas live without improved sanitation. Also the World Health Organization reported that a child dies every 15 seconds from water-related diseases. This amounts to nearly 6,000 deaths which is said to be an equivalent of 20 jumbo jets crashing every day. In 2000, the estimated mortality rate due to water sanitation hygiene-associated diarrheas and other water and/ or sanitation-associated diseases was about 2.2 million. This is because consumption of contaminated water can lead to a variety of illnesses including cholera, typhoid, and dysentery. This results to about 2.1 million deaths, which is equal to 90 percent of children under-five years of age. Water-borne parasites also cause illnesses. For example, more than 200 million people in the worldwide are infected by schistosomiasis, causing 20,000 deaths a year. An estimated 88 million of children are under fifteen years (Global Health Watch, 2005). All these result in health conditions that is generally life threatening. In Nigeria, only 31 percent of the people have access to improved sanitation facilities while about 57.4 percent have access to improved drinking water source. Annual population growth rate is 2.5 percent and an average household size is seven persons. Underfive mortality rate in Nigeria is 100 per 1000 live births and low birth weight was 26 percent. Adult literacy rate for males is 79 percent, while adult literacy rate for females is 65 percent (Multiple Indicator Cluster Survey, 2011).

According to the MDG report of United Nations (2011) for Nigeria, there has been a reasonable progress on increasing access to safe drinking water. However, rural areas are still lagging behind with more than one in ten people still without full access to safe drinking water. The health implications of inadequate access to safe water are enormous mostly for children. One of these is the endemic Malaria disease that is generally associated with unsatisfactory drinking water supplies, poor sanitation conditions and inadequate health education programs. Others include diarrhea, dysentery, gastro-enteritis, infectious hepatitis, hookworm, guinea worm, and other parasitic infections. Improving water supply infrastructure will therefore help improve the social well-being of the population.

Improved access to safe water supplies also has beneficial effects for women and girls. This is because they save the time thereof which results in reduced work load. When water must be fetched from farther locations and sometimes from multiple sources, women and girls are normally the ones who bear the burden. The time saved when there is improved access to safe water and improved sanitation can be devoted to other unpaid work such as collection of firewood or unpaid agricultural labor as well as other income generating activities (IOB, 2011). Also, large connection cost has been regarded by many literatures as one of the major obstacles to increased access particularly among the poor. It is therefore very important to consider if rural dwellers will be willing to pay and if yes, what is the amount they are willing to pay.

Studies such as those Khan et al (2010) for Northern Pakistan and Ifabiyi (2011) for households within Ilorin metropolis of Kwara state, Nigeria revealed that households' willingness-to-pay for improved drinking water was significantly determined by households' awareness, levels of education and income. While that of Herath and Masayuki (2012) for Khulna, Bangladesh showed that willingness-to-pay the monthly charge and connection cost are higher for richer households. More so, they found large connection cost to be a critical barrier to expanding the coverage most especially for the poor. For improved sanitation and 
hygiene, studies such as those of Adepoju and Salimonu (2011) for Osogbo metropolis of Osun state, Nigeria, Dagnew et al, (2012) for residents of Mekelle, Ethiopia and Kwetey et al (2014) for Tuobodom, North District of Ghana revealed that gender, age income, household expenditure, years of education, awareness of environmental quality were significantly influenced households' willingness to pay for improved sanitation and hygiene.

Previous researches as reviewed above documented the willingness to pay for safe water and improved sanitation in the urban centers with little in rural areas in North Nigeria. This article therefore aims to fill the gap in existing literature. This article will also serve as a reference for individuals and organizations as well as for the government.

\section{THEORETICAL FRAMEWORK}

\subsection{Theory of Change}

This article is hinged on the theory of Change as proposed by Water, Sanitation and Hygiene (WASH) Alliance International in 2016. It is built upon three core pillars:

i) Developing a functioning and enabling Water Sanitation and Hygiene (WASH) market, in which the private sector is providing quality products and services at an affordable price.

ii) Developing an enabling public sector for WASH, in which the government takes up its responsibility as duty bearer and creates supportive policies and regulations for sustainable WASH services.

iii) Empower, inform and organize citizens for sustainable WASH. This is essential because informed citizens will demand sustainable WASH services and practice healthy hygienic behavior. They will also enforce high quality WASH services from the market and also hold the government accountable for taking up their role as duty bearer.

A brief explanation of these pillars is given below.

\section{Pillar 1: A functioning WASH market}

This has to do with approaching households as consumers instead of beneficiaries for a WASH market to be able to function. This will encourage entrepreneurs to offer quality and affordable WASH services. This can be either through monthly tariffs or by buying the toilet or water facility with a loan or savings. However for this market to function, the government needs to provide good policies and regulations.

\section{Pillar 2: A functioning and enabling public sector for WASH}

This pillar views the provision of WASH services as the role of the government. Thus, if governments at all levels are aware of the importance of access to WASH services for sustainable economic development, know and acknowledge their role in this WASH service system, they are more likely to be willing to develop sound policies and regulations and also implement existing good policies. They will also be prepared to make enough budget available for WASH, know how to use this budget effectively and efficiently while ensuring that monitoring of WASH facilities and services function very well. This is essential as it will foster cooperation with the private sector, its citizens and the civil society.

\section{Pillar 3: Empowered and organized citizens for sustainable WASH}


This has to do with empowering and educating individual/citizens on sustainable WASH. This will help them to become aware of how healthy hygienic behavior improves their health, life and environment. As a result they will be more willing to pay for, use and maintain WASH services. This can be by organizing people in groups and providing insights in their WASH rights and responsibilities, for advocacy and for management of WASH services.

\section{METHODOLOGY}

\subsection{Study Area}

The North-central region of Nigeria consists of six states namely Kwara, Kogi, Niger, Nasarawa, Benue and Plateau as well as the Federal Capital Territory. These states are situated geographically in the middle belt region of the country spanning the west, around the confluence of the River Niger and the River Benue.

\subsection{Sampling Techniques}

The study employed a four-stage sampling technique. The first stage is the random selection of Kogi, Kwara and Niger states from the North-central region. Second is the random selection of two (2) agricultural zones from each of the three (3) states that was selected to make a total of six (6) agricultural zones. Third is the random selection of six (6) communities from each of the selected agricultural zones to make a total of thirty-six (36) communities and the last stage is the random selection of ten (10) farming households from each of the selected community to reach a total of 360 respondents. However, out of the 360 questionnaires administered in the study area, 352 were found useful for the purpose of data analyses.

\subsection{Analytical Techniques}

\section{Descriptive statistics}

Descriptive statistics such as frequencies, means, percentages, tables, bar charts, graphs etc. were used to examine the distribution of specific socioeconomic characteristics among rural households in the study area.

\section{Contingent Valuation Method}

The contingent valuation method was used to estimate the amount the rural households were willing to pay for safe water and improved solid waste management as hypothetical interventions. The hypothetical intervention scenarios were considered since it is one of the various ways through which the incidence and vulnerability to diseases can be reduced. It also improves the health status and productive capacity of the populace. These hypothetical interventions are such that could give the respondents access to a cleaner environment as well as safe and potable water. This will in turn result in a lower risk of waste and water related ailments. After describing the hypothetical intervention scenarios (proper waste management and safe water), the respondents were then asked whether they were willing to pay anything at all for any of them. Where the answer is 'no' the respondent was asked to give reason(s) and where the answer is 'yes' the respondent was asked to choose an amount from a payment list that corresponds to the maximum amount they are willing to pay for any of the hypothetical intervention scenarios. The payment lists used were generated from the price for proper waste management and potable water in the study area. It was determined from some of the households who participated in the pretest survey. 


\section{The Logistic Model}

The logistic model was used to estimate the willingness to pay for these hypothetical interventions by rural households. It has the form

Logit $(Y)=$ natural $\log ($ odds $)=\ln \left(\frac{\pi}{1-\pi}\right)=\alpha+\beta X$

$\pi=$ probability $(Y=$ outcome of interest $/ X=x$, a specific value of $\mathrm{X})=\frac{e^{\alpha+\beta x}}{1+e^{\alpha+\beta x}}$

Where: $\pi=$ probability of the outcome of interest

$\alpha=$ intercept of $Y$

$\beta=$ Regression coefficient

$e=2.71828$ (base of natural logarithims)

Where:

$Y_{i}=$ Willingness to pay for any of the hypothetical interventions (Proper solid waste management and Safe water) (Yes $=1,0=$ otherwise)

$\mathrm{X}_{1 \mathrm{i}}, \mathrm{X}_{2 \mathrm{i}} \ldots \mathrm{X}_{\mathrm{ni}}=$ vectors of explanatory variables

Where;

$\beta_{0}, \beta_{1} \ldots \beta_{n}=$ coefficients of explanatory variables

$$
\begin{aligned}
& \mathrm{X}_{1}=\text { Gender of household head }(\text { Yes }=1,0 \text { otherwise) } \\
& \mathrm{X}_{2}=\text { Age of household head (years) } \\
& \mathrm{X}_{3}=\text { Years of schooling of household head } \\
& \mathrm{X}_{4}=\text { Membership of cooperative societies (Yes }=1,0 \text { otherwise) } \\
& \mathrm{X}_{5}=\text { Health status (Normal }=1,0=\text { obese or lean) } \\
& \mathrm{X}_{6}=\text { Dependency ratio } \\
& \mathrm{X}_{7}=\text { Income (N/month) }
\end{aligned}
$$

\section{Tobit model}

The tobit model was further used to assess the determinants of the maximum amount the rural households were willing to pay for each of the hypothetical intervention. The tobit model can be written as:

Where:

$$
y_{i}^{*}=\beta x_{i}+u_{i}, \quad u_{i} N\left(0, \sigma^{2}\right)
$$

$\mathrm{Y}_{\mathrm{i}}=$ Maximum amount they are willing to pay for any of the hypothetical interventions (Proper solid waste management and Safe water).

$\mathrm{X}_{1 \mathrm{i}}, \mathrm{X}_{2 \mathrm{i}} \ldots \mathrm{X}_{\mathrm{ni}}=$ vectors of explanatory variables

Where;

$\beta_{0}, \beta_{1} \ldots \beta_{n}=$ coefficients of explanatory variables

$\mathrm{X}_{1}=$ Gender of household head $(\mathrm{Yes}=1,0$ otherwise $)$

$\mathrm{X}_{2}=$ Age of household head (years)

$\mathrm{X}_{3}=$ Years of schooling of household head

$\mathrm{X}_{4}=$ Membership of cooperative societies (Yes $=1,0$ otherwise).

$\mathrm{X}_{5}=$ Health status (Normal $=1,0=$ obese or lean)

$\mathrm{X}_{6}=$ Dependency ratio

$\mathrm{X}_{7}=$ Income ( $\mathrm{N} /$ month) 


\section{RESULTS and DISCUSSION}

\subsection{Socioeconomic Characteristics}

Table 1. Socioeconomic Characteristics

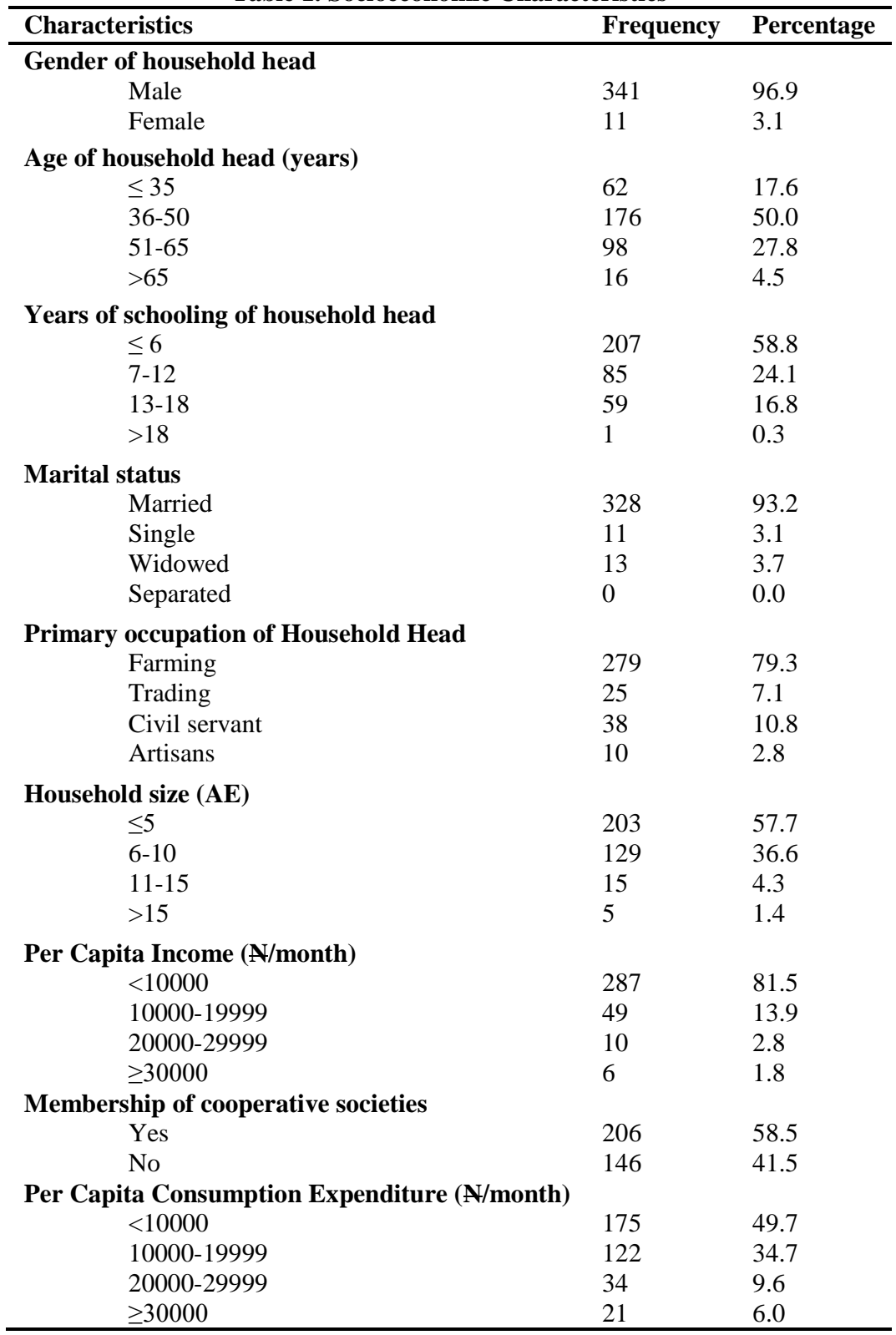

Source: Field survey data, 2015, No of observation = 352 households; AE=Adult Equivalent.

Table 1 shows the male headed households are 96.9 percent as against the 3.1 percent of female household head. Age is also another important socio-economic characteristics, the modal age of the household heads was between 36-50 years which accounts for 50 percent of the rural households. Only 4.5 percent of them were above 65 years of age. This implies that 
most of the respondents in the study area are in the active and agile age bracket. About 93.7 percent of the total respondents were also married. This might account for the presence of large households in the study area with 57.7 percent of the total rural households having about 5 members per household.

About 79.3 percent of the respondents engaged in farming as their primary occupation with 58.8 percent of the household heads have just about six (6) years of schooling. This implies that they stopped schooling at primary school level. Education is an important variable that is expected to have important effect on the decisions they make (William, 1999). This will in turn improve productivity, health status as well as reduce the negative features of life (UNESCO, 2002). Also, majority (58.5 percent) of them were also members of cooperative society which implies that they will have opportunity to benefit from what the members shared. This may include proper education on the various risk factors they are exposed to as rural dwellers as well as how to prevent some diseases within their communities among others. These results are not too different from that of Oyekale \& Eluwa (2009;70-75) and Babatunde et al (2012;133-142) as the range of characteristics typical of rural communities in Nigeria. Table 1 further shows that 81.5 percent of the rural household earn about N10,000 as Per Capita Income (PCI) and also majority of the households spends about N10,000 per month and this accounts for 49.7 percent of the sampled households.

\subsection{Willingness to Pay Analysis}

This section consists of the results of the analysis of farming households' willingness-to-pay for hypothetical interventions (proper solid waste management and safe water). The tools of analysis used in this section are the contingent valuation method, logistic and tobit models. The results are presented in tables 2, 3 and 4.

Table 2. Willingness-to-pay Analysis

\begin{tabular}{|c|c|c|c|}
\hline \multirow[t]{2}{*}{ Hypothetical interventions } & \multicolumn{2}{|c|}{ Willing-to-pay } & \multirow[t]{2}{*}{ Average Amount } \\
\hline & Frequency & Percentage & \\
\hline $\begin{array}{l}\text { Proper Solid waste } \\
\text { Management }\end{array}$ & 97 & 27.6 & N176/week \\
\hline Safe and Potable Water & 106 & 30.1 & N21.6/20 litres \\
\hline
\end{tabular}

Source: Field Survey data, 2015; Number of observation $=352$ farming households

Results in table 2 shows that only 28 percent were willing-to-pay an average of N176 per week for proper solid waste management and 30 percent were willing-to-pay an average of N22 for every 20 liters of potable water. This may be attributed to the fact that rural households are not very enlightened as to the benefit that can be derived from taking preventive measures (such as access proper solid waste to management and safe water) that can enhance their health status and wellbeing. This result is not too different from that of Ezebilo (2013; 413-422) who also worked on a study regarding households' willingness to pay for improved residential solid waste management. He found an average of N3, 660 per year.

To further consolidate the results in table 2 above, the study examined the determinants of their willingness-to-pay, marginal effects and the amount using logistic and tobit regression respectively. These results are presented in tables 3 to 4 . 
Table 3. Determinants of Willingness to Pay for Proper Solid Waste Management

\begin{tabular}{|c|c|c|c|}
\hline \multirow[t]{2}{*}{ Variables } & \multicolumn{2}{|c|}{$\begin{array}{l}\text { Logistic estimation of WTP } \\
\text { (Yes }=1,0 \text { otherwise) }\end{array}$} & \multirow{2}{*}{$\begin{array}{l}\text { Tobit estimation } \\
\text { of maximum } \\
\text { amount WTP } \\
\text { Estimates }\end{array}$} \\
\hline & Estimates & Marginal effects & \\
\hline Gender of household head (Male $=1$ ) & $\begin{array}{l}-2.10 * * * \\
(-6.24)\end{array}$ & $\begin{array}{l}-0.33 * * * \\
(-7.91)\end{array}$ & $\begin{array}{l}-256.79 * * * \\
(-6.31)\end{array}$ \\
\hline Age of household head(years) & $\begin{array}{l}-0.02 \\
(-1.13)\end{array}$ & $\begin{array}{l}-0.00 \\
(-1.13)\end{array}$ & $\begin{array}{l}-1.05 \\
(-0.65)\end{array}$ \\
\hline Years of Schooling & $\begin{array}{l}-0.00 \\
(-0.11)\end{array}$ & $\begin{array}{l}-0.00 \\
(-0.11)\end{array}$ & $\begin{array}{l}-2.88 \\
(-0.89)\end{array}$ \\
\hline Members of cooperative society & $\begin{array}{l}0.85 * * * \\
(2.95)\end{array}$ & $\begin{array}{l}0.13 * * * \\
(3.05)\end{array}$ & $\begin{array}{l}111.08^{* * * *} \\
(3.25)\end{array}$ \\
\hline Health status (Normal $=1,0$ otherwise) & $\begin{array}{l}0.47 * \\
(1.17)\end{array}$ & $\begin{array}{l}0.07 * \\
(1.73)\end{array}$ & $\begin{array}{l}54.70^{*} \\
(1.69)\end{array}$ \\
\hline Dependency ratio & $\begin{array}{l}1.25 * * * \\
(2.93)\end{array}$ & $\begin{array}{l}0.20 * * * \\
(3.04)\end{array}$ & $\begin{array}{l}172.32 * * * \\
(3.66)\end{array}$ \\
\hline Income ( $\mathrm{N} /$ month) & $\begin{array}{l}2.84 \mathrm{e}-06 \\
(1.45)\end{array}$ & $\begin{array}{l}4.49 \mathrm{e}-07 \\
(1.47)\end{array}$ & $\begin{array}{l}0.00 \\
(1.52)\end{array}$ \\
\hline Constant & $\begin{array}{l}0.06 \\
(0.07)\end{array}$ & & $\begin{array}{l}-33.92 \\
(-0.33)\end{array}$ \\
\hline $\operatorname{LRchi}^{2}(7)$ & $70.66^{* * *}$ & & $72.93 * * *$ \\
\hline Log-likelihood & -171.8972 & & -736.4438 \\
\hline
\end{tabular}

Source: Field Survey data, 2015; Number of observation $=352$ farming households

$*$, *** indicate significant levels of $10 \%$ and $1 \%$ respectively

Figures in bracket represent the z-values for logistic estimates and t-values for the tobit estimates.

Table 3 shows the logistic and tobit results of the factors that determine the willingness-topay, marginal effects as well as the maximum amount rural households are willing-to-pay for proper solid waste management. The result shows that the gender of household head, membership of cooperative societies, dependency ratio, health status and the monthly income of the household head are the significant factors that determine the rural households' willingness-to-pay for proper solid waste management. Also, all these factors were found to significantly influence the maximum amount the rural households were willing-to-pay for proper solid waste management. This implies that female headed households, household heads who are members of cooperative societies, have more dependents within their households and those who have normal BMI (those that were found to be healthy) are more likely to be willing-to-pay for proper solid waste management. This may be attributed to the fact that female headed households who have more number of dependents (children below 15 years and adults above 60 years of age) are more aware of the need and effect of clean physical environment and as such will be more willing-to-pay to achieve this. Also, individuals who are members of social groups like cooperative societies are likely to be more exposed to the health benefits inherent in proper solid waste management both for the members of his/her immediate households and the community within which he/she finds him/herself.

The results of the marginal effects also in table 3 shows that holding other variables constant for each of the variables that were significant, a unit increase in the number of dependents within in an household, female headed households, member of a cooperative society and those that were found healthy (those with BMI ranging from $18.5 \mathrm{~kg} / \mathrm{m} 2$ to $24.99 \mathrm{~kg} / \mathrm{m} 2$ ) have 
the likelihood of increasing their willingness-to-pay for proper solid waste disposal by 20,33 , 13 and 7 percent respectively.

This result is consistent with those of Adepoju \& Salimonu (2011), Dadson et al., (2013), Ezebilo (2013) and Kwabena \& Gideon (2014) for a related study in Osun state, Nigeria, Kumasi, Ghana, Kwara state, Nigeria and Dunkwa-on-offin, Ghana respectively.

Table 4. Determinants of Willingness to Pay for Potable Water

\begin{tabular}{|c|c|c|c|}
\hline & Estimates & Marginal effects & Estimates \\
\hline Gender of household head (Male $=1$ ) & $\begin{array}{l}-0.44 \\
(-0.87)\end{array}$ & $\begin{array}{l}-0.06 \\
(-0.87)\end{array}$ & $\begin{array}{l}-6.71 \\
(-1.20)\end{array}$ \\
\hline Age of household head(years) & $\begin{array}{l}0.02 \\
(1.07)\end{array}$ & $\begin{array}{l}0.00 \\
(1.08)\end{array}$ & $\begin{array}{l}0.14 \\
(0.92)\end{array}$ \\
\hline Years of Schooling & $\begin{array}{l}0.22 * * * \\
(8.32)\end{array}$ & $\begin{array}{l}0.03 * * * \\
(14.50)\end{array}$ & $\begin{array}{l}2.31 * * * \\
(8.02)\end{array}$ \\
\hline Members of cooperative society & $\begin{array}{l}1.06^{* * * *} \\
(3.28)\end{array}$ & $\begin{array}{l}0.15 * * * \\
(3.48)\end{array}$ & $\begin{array}{l}10.83 * * * \\
(2.80)\end{array}$ \\
\hline Dependency ratio & $\begin{array}{l}1.04 * * \\
(2.28)\end{array}$ & $\begin{array}{l}0.15 * * \\
(2.34)\end{array}$ & $\begin{array}{l}13.80 * * * \\
(2.58)\end{array}$ \\
\hline Health Status (Normal $=1.0$ otherwise) & $\begin{array}{l}0.15 \\
(0.51)\end{array}$ & $\begin{array}{l}0.02 \\
(0.51)\end{array}$ & $\begin{array}{l}1.30 \\
(0.39)\end{array}$ \\
\hline Income ( $\mathrm{N} /$ month) & $\begin{array}{l}-0.00 * * \\
(-2.20)\end{array}$ & $\begin{array}{l}-7.21 \mathrm{e}-06^{* * *} \\
(-2.26)\end{array}$ & $\begin{array}{l}-0.00 \\
(-1.37)\end{array}$ \\
\hline Constant & $\begin{array}{l}-4.33 * * * \\
(-4.30)\end{array}$ & & $\begin{array}{l}-40.27 * * * \\
(-4.08)\end{array}$ \\
\hline $\operatorname{LRchi}^{2}(7)$ & $131.30 * * *$ & & $104.69 * * *$ \\
\hline Log-likelihood & -156.7505 & & -625.5254 \\
\hline
\end{tabular}

Source: Field Survey data, 2015; **, *** indicate significant levels of 5\% and 1\% respectively. Figures in bracket represent the z-values for logistic estimates and t-values for the tobit estimates.

The result shows that the years of schooling, membership of cooperative societies, dependency ratio and the monthly income of the household heads are the significant factors that determine the rural households' willingness-to-pay for safe and portable water. This implies that household heads with more years of schooling which are members of cooperative societies, those with a larger proportion of their households as dependents (younger than 15 years and older than 60 years) are more likely to be willing-to-pay for safe and potable water. This may be attributed to the fact that households with increased years of schooling and are members of cooperative societies are likely to be more exposed to the health benefits of having access to portable water and as such will be willing-to-pay for it. It is however important to note that the negative coefficient for the monthly income which was also found to be significant contradicts a priori expectations but can be said to reflect the nature of the commodity (water). Safe and potable is an example of a private good/commodity whose demand is inelastic in nature (in this case not necessarily dictated by increased income level). It is a basic necessity upon which good health depends. Hence in this case, when the level of income decreased, rural households in North-Central Nigeria were willing to pay more for safe and potable water.

Furthermore, the results of the marginal effects also in table 4 shows that holding other variables constant for each of the variables that were significant, a unit increase in years of schooling has the likelihood of increasing rural households' willingness-to-pay for safe and potable water by 3 percent. So also, as the dependency ratio increases and becoming a member of any cooperative society have the likelihood of increasing rural households' 
willingness-to-pay for safe and potable water by 15 percent respectively. This result is not different from the findings of Khan et al., (2010) for northern Pakistan, Ifabiyi (2011) for Ilorin, Kwara state, Nigeria and Mohd et al., (2013) that all came to a consensus that the level of education (related to years of schooling used in this study) is an important factor determines willingness-to-pay for improved drinking water sources.

\section{CONCLUSION and RECOMMENDATION}

The article revealed that only 27.6 and 30.1 percent of the sampled rural households were willing to pay for proper solid waste management and potable water respectively. Also, the significant determinants of the amount these households are willing to pay include the gender and years of schooling of the household head, membership of cooperative societies, dependency ratio, health status and monthly income of the household head. This study therefore recommends that governmental and private organizations should engage on intensive health education in the rural areas emphasizing the need and importance of a clean environment. This will increase the awareness of the rural dwellers thus their willingness to pay. It will also improve the health status of the rural populace; increase the quality of labor available for production thereby enhancing sustainable economic development.

\section{REFERENCES}

ADEPOJU, A. A., \& SALIMONU, K. K (2011). Household Willingness to Pay For Improved Solid Waste Management In Osun State, Nigeria. Department of Agricultural Economics, Ladoke Akintola University of Technology, Ogbomoso, Oyo state.

BABATUNDE O.A., AKANDE T. M., SALAUDEEN A. G., ADERIBIGBE S. A., ELEGBEDE O. E. \& AYODELE L. M. (2012). Willingness To Pay for Community Health Insurance and its Determinants Among Household Heads in Rural Communities in North-Central Nigeria. International Review of Social Sciences and Humanities. Vol. 2 (2): 133-142

Central Intelligence Agency (CIA) World Fact book (2015).

DADSON, A., SHAIBU, I. \& GODFRED, S. J. (2013). Urban Households' Willingness to Pay for Improved Solid Waste Disposal Services in Kumasi Metropolis, Ghana. Urban Studies Research, volume 2013, Article Id 659425.

EZEBILO, E. E. (2013). Willingness to Pay For Improved Residential Waste Management in a Developing Country. Int. J. Environ. Sci. Technol. (2013) 10:413-422

GLOBAL HEALTH WATCH (2005). Global-health problem. The Lancet 367(9521): 15331540.

HERATH, G. \& MASAYUKI, T. (2012). Willingness to pay and inclusive tariff designs for improved water supply services in Khulna, Bangladesh. Asia Development Bank, Working Paper Series, WPS-124243

IFABIYI, I.P. (2011). Willingness to Pay For Water at Household Level in Ilorin, Kwara State, Nigeria. Global Journal Of Human Social Science Volume 11 Issue 2 Version 1. 
IOB (2012). From infrastructure to sustainable impact: policy review of the Dutch contribution to drinking water and sanitation $(1990$ - 2011). The Hague: Ministry of Foreign Affairs, Policy and Operations Evaluation Department.

KHAN, H., FAIZA, I., SAEED, I. AND KHAN, I. (2010). Estimating Willingness to Pay for Improvements In Drinking Water Quality: Evidence From Peshawar, Northern Pakistan. Environmental Economics, Volume 1, Issue 2.

KWABENA, N. A. \& GIDEON, D. (2014). Determinants of Willingness to Pay for Improved Solid Waste Management in Dunkwa-On-Offin, Ghana. Journal of Agriculture and Environmental Sciences, Vol. 3, No. 1, Pp. 01-09

KWETEY, S., COBBINA, S. J., ASARE, W. \& DUWIEJUAH, A. B. (2014). Household demand and willingness to pay for solid waste management service in Tuobodom in the Techiman-North District, Ghana, American Journal of Environmental Protection, Vol. 2, No. 4, 74-78

MOHD, R. Y., SUlEIMAN, A. D., ALIAS, R. \& ZAITON, S. (2013). Household's Willingness to Pay for Drinking Water Quality Service Improvement in Damaturu, Nigeria. Current World Environment, Vol. 8(3), 381-389.

MULTIPLE INDICATOR CLUSTER SURVEY REPORT (2011)

OYEKALE S. \& ELUWA C. (2009). Utilization of Health-care and Health Insurance among Rural Households in Irewole Local Government, Osun State, Nigeria. International Journal of Tropical Medicine 4(2): 70-75.

UNITED NATIONS EDUCATIONAL, SCIENTIFIC AND CULTURAL ORGANIZATION (2002). Global monitoring report education: for all: Is the world on track. UNESCO, Paris.

UNITED NATIONS EDUCATIONAL, SCIENTIFIC AND CULTURAL ORGANIZATION (2006). Water: a shared responsibility, The United Nations World Water Development Report 2. Paris.

WASH ALLIANCE (2016). https://wash-alliance.org>sites>2016/06

WILLIAM, L. (1999). Quality Improvement in Undergraduate Education, Proceedings of the Inaugural Conference of the Global Consortium of Higher Education and Research for Agriculture, July 22-24, 1999, Amsterdam, The Netherlands

WORLD HEALTH STATISTICS (2014) 